\title{
FEATURES OF THE USE OF FILM ANALYSIS IN DEALING WITH GENDER ISSUES
}

\section{Tetiana Kostina ${ }^{1}$}

\section{DOI: https://doi.org/10.30525/978-9934-588-11-2_31}

Today, the issue of reform is particularly acute for Ukrainian society. As our country's desire to become part of the European Union requires it to comply with the relevant rules at the legislative level. However, equally important is the desire to uphold the values that are important to a democratic society. One of such values for Ukraine should be gender equality. The issue of equality must be raised at different levels and in different areas of our society. Gender mainstreaming is of particular importance in the field of education. After all, it is in this field that the foundations are laid, which play a key role in shaping a person's worldview, his or her ability to profess democratic values.

That is why the search for effective educational methods that can be used in the field of gender issues remains relevant for modern Ukrainian education [3]. Therefore, more and more scholars and teachers are attracting the means of nonformal education, which can be referred to as the method of film analysis.

Film analysis is widely used in psychology. It was used by such psychologists as: J. Lacan, J. Campbell, S. Zizek [2]. The advantages of this method include: relative ease of use, the ability to reach a sufficient number of audience, a significant impact on human consciousness.

In general, the researchers identify two models of movie viewing.

The first option. Watching the movie as an «alien world» that the individual cannot join. Usually these are films whose main purpose is to distract a person from his or her life problems, that is, to entertain. In this case, there is no deep effect on the psyche and the unfolding of self-reflection.

The second option involves emotional involvement, involving the viewer in what is happening on the screen, as if in the «mirror» of his being [1]. Such a model emphasizes the need for a sound approach to the selection of films: they (films) must accommodate the problems that exist in real life.

To use the film-analysis method, the teacher / psychologist should remember the following.

1) Choice of film / film production to be shown to students. In the context of gender equality, films that have a direct bearing on the subject of gender inequality and gender discrimination should be selected.

2) Choose the form of conducting: group / individual. The film-analysis method can be used both in bulk and individually. The choice of the form depends on the opportunities available to the teacher / psychologist. First of all, it is time and technical. The group form requires the availability of time (the length of the movie and its

\footnotetext{
${ }^{1}$ V.I. Vernadsky Taurida National University, Ukraine
} 
subsequent discussion) during which the group members must be indoors and watch the movie. Conditions must be created under which the review should not be interrupted by external factors. In addition, there must be adequate technical support for the group viewing, such as a projector or interactive whiteboard that will show the movie production. In the absence of the necessary resources, the movie can be viewed individually: participants are provided with information about the movie (name, director, year of release) and set timeframes when they need to watch (eg, a week).

3) To determine how feedback from group members. We emphasize that the method of film analysis assumes the presence of feedback. Because the goal is not just reviewing the movie, the goal is to update the students certain experiences to enrich their knowledge and new experience. Therefore, a prerequisite is the elaboration of the information (including psychological component) that is present in the film. Therefore, if viewing of the film took place in the group, after viewing, you should organize a debate-discussion. The teacher/counselor in advance to prepare questions for discussion and to think through the organization so that the discussionthe discussion was attended by all participants. We emphasize that this method of feedback is the most optimal because it allows immediately to study the material (including psychological), which was received by group members during the viewing.

When viewed individually, the feedback can be realized in the form of an essay reflection on the film's story (impressions of the film, the importance of the topic for modern society, etc.). Writing an essay gives young people the opportunity to structure their experiences and share their experiences with writing in writing.

We emphasize that the use of the method of film analysis is usually accompanied by other methods (seminars, trainings, etc.) that contribute to the formation of gender competence of young people. In this article, we want to emphasize the potential of gender-based film analysis. In addition, depending on the purpose and issue, different films can be selected to cover the necessary aspect (gender discrimination, domestic violence, women's rights violations, etc.).

The general scheme of film analysis may include the following elements:

- preparatory phase (the teacher chooses a film that should update the topic: in our case, it is a gender issue),

- own movie viewing (group / individual),

- final stage (includes reflection on the information received and can be held in the form of discussion, essay reflection, etc.).

Therefore, one of the methods that can be used when working with young people in the context of gender is film analysis. This method is quite simple and does not require too much effort from the psychologist / teacher. However, in spite of its simplicity, film analysis has a significant psychological effect on personality and can be used on a variety of topics, including gender. 


\section{References:}

1. Voznesenska, O., \& Holubieva, O. (2011). Kinoterapiia yak forma mediaosvity [Cinema therapy as a form of media education]. (ukr). Retrieved from: https://ms.detector.media/ mediaprosvita/mediaosvita/kinoterapiya_yak_forma_mediaosviti/(accessed 23 September 2019).

2. Lozynskyi, O., \& Kozhushko-Lozynska, I. (2018). Psykholohiia kinomystetstva ta kinematohrafichni upodobannia molodi [Psychology of cinema and cinematographic preferences of young people]. Lviv, Ukraine: Lvivskyi politekhnichnyi natsionalnyi universytet (ukr). Retrieved from: http://ena.lp.edu.ua:8080/bitstream/ntb/42261/2/2018v11_Lozinskii_O-Psykholohiia_ kinomystetstva_165-180.pdf (accessed 21 September 2019).

3. Hovorun, T., \& Kikinezhdi, O. (Eds.). (2006). Yak navchaty shkoliariv dolaty genderni stereotypy: konspekty zaniat [Teaching students to overcome gender stereotypes: lesson notes]. Kyiv: TOV «Dorado-Druk». (in Ukrainian) 